\title{
Research on the Growth Rules and Development Paths of Innovative
}

\section{Talents}

\author{
Qian Cheng ${ }^{1,2}$ \\ ${ }^{1}$ School of Business Administration, Zhejiang Gongshang University, Hangzhou, Zhejiang, China, \\ 310018 \\ ${ }^{2}$ Zhejiang Financial College, Hangzhou, Zhejiang, China, 310018
}

Keywords: Innovative Talents, Growth Pattern, Growth Path

\begin{abstract}
With the development of economic globalization and the increasingly fierce international competition, science and technology have become the decisive force in economic and social development. The competition between countries and regions is essentially the competition of science and technology innovation ability, and the key to improve the ability of innovation is talent. Based on the author's practical experience, this paper firstly analyzes the rules of the growth of innovative talents, and on this basis, it discusses the paths of the development of innovative talents.
\end{abstract}

\section{The Growth Rules of Innovative Talents}

Type of accumulating experience. From perceptual to rational, from experience to theory, this is the basic law of human understanding of things. Through innovative practice to understand the rule of innovation activities, constantly to solve various problems in innovation activities, constantly to correct their own way of thinking and thinking. After a variety of success and failure, the psychological quality and knowledge structure required by innovation, capacity reserve can be adjusted, forming its own innovative personality, so that it can be found in the ordinary people seem to have no problem at all. For the same problem, they are able to put forward new ideas before the ordinary people, showing extraordinary innovation performance. In the history of the various masters, the person who can be called innovative talents got a brilliant achievements relying on experience accumulation. Since modern times, the famous scientists and inventors emerged in the process of the third science and technology revolution, From Copernicus, Galileo, Newton to Planck and Einstein, their success and productivity showed their extraordinary innovation performance, at the same time it also shows that they has accumulated extraordinary innovation experience relying on innovative practice. The regal ranked in the top 10 in China's rich list all showed corresponding features. We have to admit that these extraordinary achievements of the rich are innovative talent, and their ability to innovate is clearly not a direct result of education, but they ultimately succeed relying on innovative practice in the continuous.

Type of environmental experience. The impact of the environment on the growth of people is self-evident, everyone's life and work environment is different, and sometimes even determine their growth trajectory. The development of innovative talent is no exception, and the case study can prove that the special environment of experience is a pattern of experience accumulation. Environmental experience mode means that it is a passive, helpless in the same environment to fight, relying on their own efforts to fight for the survival and development of the right. In the process of changing the state of life, through constant innovation and practice, the accumulation of innovative experience, forming the innovative quality and innovative ability, at the same time, by the success 
of the struggle to be recognized as an innovative talent. Mao Zedong is a innovative talent trained in the harsh life and work environment in military phase. He didn't read the military school one day, and it is the environmental experience that makes him accumulate a lot of experience, forming a set of strategies and tactics of the world military science.

Type of paradigm effect. The paradigm effect means that the growth of an innovative talent recognized by the community, even a successful innovation case, and it can provide more people with innovative demonstration, make more people on the road to innovation, therefore, we can follow the growth model of people who have achieved success in innovation practice by following the character structure of innovative talents, the way of thinking and the spirit of challenge. In 1839, based on the the process and methods Schleiden finding plant cells, Berlin University physiologist Schwann anatomy found the animal cells, and then found the unity of the microstructure in the process of the growth development of animal and plant, which is the formation of the cell theory of landmark significance. Based on Newton's theory of universal gravitation, integrating two formulas for the wavelength distribution of energy radiation put forward by Rayleigh Jens and Waynes, Planck proposed the concept of quantum energy and a universal formula for the density of energy radiation, which solved a major problem in the field of physics in the early twentieth Century, and thus created the quantum mechanics, causing the revolution in physics, and even the entire natural science revolutionary development.

Type of education and training. Education is the main channel to cultivate creative talents. The above three models do not exclude the role of various educational institutions and systems in the training of innovative talents, but in different countries, the educational system, especially the educational objectives and educational ideas are different. From 1940s to 1970s, the United States aims to clear the educational system, which has played a very important role in training a large number of innovative talents. Through the comparative study of Chinese and American Education, China's education is mainly to teach students "what is", however, the American education is to lead students to explore "why" and "how to do it", so we can see that the utility of the cultivation of innovative talents is self-evident. Innovative education is the main channel to cultivate innovative talents, rather than the kind of education thought and education system that is primarily aimed at imparting knowledge or skills. Innovative education should take training innovative talents as the purpose of all educational activities, and aiming at the cultivation of innovative talents, the goal is divided into the corresponding teaching links, so that students not only master the theoretical knowledge of innovation activities, training of creative thinking and personality quality, but also a combine the professional courses for innovative practice. Through innovative education and training of innovative talents, the performance should be rational in the concrete innovation practice. This mode of training innovative talents can greatly shorten the growth cycle of a new talent, and in turn promote the social science and technology, culture and art, and even the prosperity and development of the economy.

Type of self-cultivation. This model is a process to find out the gap, to actively strengthen the practice of some aspects of the practice based on their corresponding quality and ability level according to the social evaluation standard of innovative talents. Bill Gates did not graduate on the beginning of their own entrepreneurial process, and finally gets an amazing success; Hua Luogeng has not received formal training, bubt he has become China's leader in applied mathematics. Their talent pattern belongs to the self discipline class without exception. As long as you want to be creative talent, every one of us can make the dream come true through self cultivation. 


\section{The Growth Paths of Innovative Talents}

Optimizing the educational idea. Each teaching link is the specific measures to cultivate talents, whether teaching content, teaching method, teaching method or teaching method, it should be integrated into innovative thinking. We should inspire students to innovate, each person's innovative ability is unlimited, and the key is how to open the door of innovation. In each teaching practice link, we must change the teaching idea, implementing "originality - innovation - entrepreneurship Wealth" education. With originality, it is possible to carry out innovation; With innovation, it is possible to carry out entrepreneurship, and then creating a lot of wealth for the society. Thus it can be seen that they are complementary to each other, the former lays a solid foundation for the latter, and the latter is the sublimation of the former.

Guiding students to correctly assess their intellectual structure. This is the key to cultivate innovative talents. In teaching innovation, teachers should first learn to assess their own intellectual structure, to play their own advantages, to avoid their own weaknesses, to take their own path of innovation and growth, which is more likely to produce creative results. The intelligence structure mainly consists of observation ability, memory ability, thinking ability, imagination ability, operation ability and so on. In the intellectual structure, the most important is the creative thinking and creative imagination, and these two kinds of ability constitute the human creative ability. Each teacher can choose basic research, applied research and development research and other different types of topics according to the characteristics of their intellectual structure. When a student is able to make a correct assessment of his intellectual structure, it is possible to choose the right type of research for yourself, so as to effectively create the invention. Practice has proved that in only engaged in research in the field of intellectual structure can they maximize their potential to engage in the creation of the invention,

Guiding students to grasp the correct technical development ideas. Any innovation, ultimately will be converted into technology and services for the progress of human civilization. In the cultivation of innovative talents, it should also pay attention to the cultivation of students' ability of technological innovation. The key to cultivating the ability of technological innovation is to master the correct technical development ideas. The generally idea of technical development is that taking the scientific development and high technology information as the basis for science and technology, to carry out the overall planning concept, planning, and then proceeding to research; Through practical research to achieve the product, followed by the formation of goods, continue to develop, to mass production; The final products are gradually replaced by other technologies, products. If technological development is to succeed in obtaining technical, economic and social benefits, the following principles must be observed: Market and information oriented, taking product as an object, based on the research of high technology and applied technology, in order to achieve the ultimate goal of commercialization, commercialization and industrialization.

\section{Conclusion}

The cultivation of innovative talents is of great strategic significance to the society and the furniture of the country, so how to train the excellent talents has become a hot research direction. Many scholars have made a contribution to the cultivation of innovative talents. This paper studies the rules of the growth of innovative talents, and summarizes the paths of training innovative talents, in order to make my own contribution to cultivate innovative talents, hoping the aspiring scholars should be bold in exploration and innovation, become an outstanding innovative talents and make a 
contribution to society and the country.

\section{References}

[1] Guo Shitian. Research on the development of innovative talents in contemporary China [D]. Shandong University, 2012

[2] Liu Linlin. Research on the law and path of the growth of innovative talent [J]. scientific management research, 2014,01:82-85.

[3] Yan Guangcai. Study on the top-notch innovative academic talents training from the law of growth[J]. higher education in China, 2011,01:37-39.

[4] Wei Fachen. The law of the development of innovative talents and self cultivation[J]. Journal of Beijing Institute of Technology (SOCIAL SCIENCE EDITION), 2007,05:106-109. (in Chinese).

[5] Wang Lulu. Research on the growth environment of enterprise innovative scientific and technological talents [D]. Harbin Engineering University, 2010 